\title{
Positive Psychology and Well-Being at Sea
}

\author{
Joanne McVeigh, Malcolm MacLachlan, Ralf Stilz, Henriette Cox, \\ Niamh Doyle, Alistair Fraser and Marianne Dyer
}

\section{Case Study}

The Shell Health Resilience Programme was developed to promote thriving of workers on and off shore. It is a voluntary resilience intervention comprising 12 modules based on positive psychology, cognitive behavioural therapy, neuro-linguistic programming, and research on leadership. The programme is delivered to individual teams by lay facilitators who are usually team members. The 12 modules are driven by team interaction, with the facilitator setting the scene and coordinating activities and discussion. The programme can be completed as slowly or as quickly as desired by the team. Prior to trialling at sea, the programme had already been adopted in multiple locations onshore.

Adoption at sea posed some challenges due to circumstances specific to life on a ship. The ships were in remote locations most of the time, limiting the availability of seafarers for training as facilitators. This also meant that more facilitators needed to be trained as each ship required their own facilitator. The working pattern required seafarers to stay on board for several months, followed by a similar length of shore leave, meaning that a sufficient number of facilitators needed to be available on each ship to ensure continuity of the programme. The staggered

\footnotetext{
J. McVeigh ( $ه) \cdot$ M. MacLachlan

Centre for Global Health and School of Psychology, Trinity College Dublin,

7-9 Leinster Street South, Dublin, Ireland

e-mail: jmcveigh@tcd.ie

R. Stilz · A. Fraser · M. Dyer

Shell Health, London, UK

H. Cox

Shell International Trading and Shipping Company Limited, London, UK

N. Doyle

University College Cork, Cork, Ireland

(C) Springer International Publishing Switzerland 2017

M. MacLachlan (ed.), Maritime Psychology, DOI 10.1007/978-3-319-45430-6_2
} 
changeover of crew on each ship resulted in team members participating in a dissimilar combination of modules. In addition, some crew members also changed ship after completing one trip. Furthermore, online information and additional material was available to support facilitators in shore-based locations, but was not routinely accessible at sea.

To overcome some of these obstacles, the programme was adapted and trialled in a pilot with 21 ships. Materials for the modules and supporting information were compiled and tailored to the needs of the seafarers and prepared for offline use. Each ship in the pilot study was equipped with all materials required. A small number of facilitators were trained during a one-hour session at an annual onshore officers' conference. Officers rather than non-officer ranks were selected as they usually deliver routine training on the ships and were thus thought to be more comfortable with the role of a facilitator. Officers were asked to train up a facilitator on board their ship before completing their trip and disembarking. Joint preparation and facilitation of modules by more than one facilitator was encouraged.

A number of innovative examples of module facilitation were shared by the seafarers:

- Several seafarers created presentations for facilitating the programme, shared their personal experiences and reframed the module content in their own words, translating the programme into their cultural and occupational context.

- On one ship, everyone participated in the module preparation and faciliation. This ship chose to complete all of the modules on a single training day, rather than spreading out the delivery over several months.

These examples bear testimony to the seafarers' engagement with, and taking ownership of, the resilience programme. Feedback from the seafarers was positive: "This module brought some lively discussions in the groups" and "Wonderful experience conducting resilience workshop on board. It was indeed amazing to see

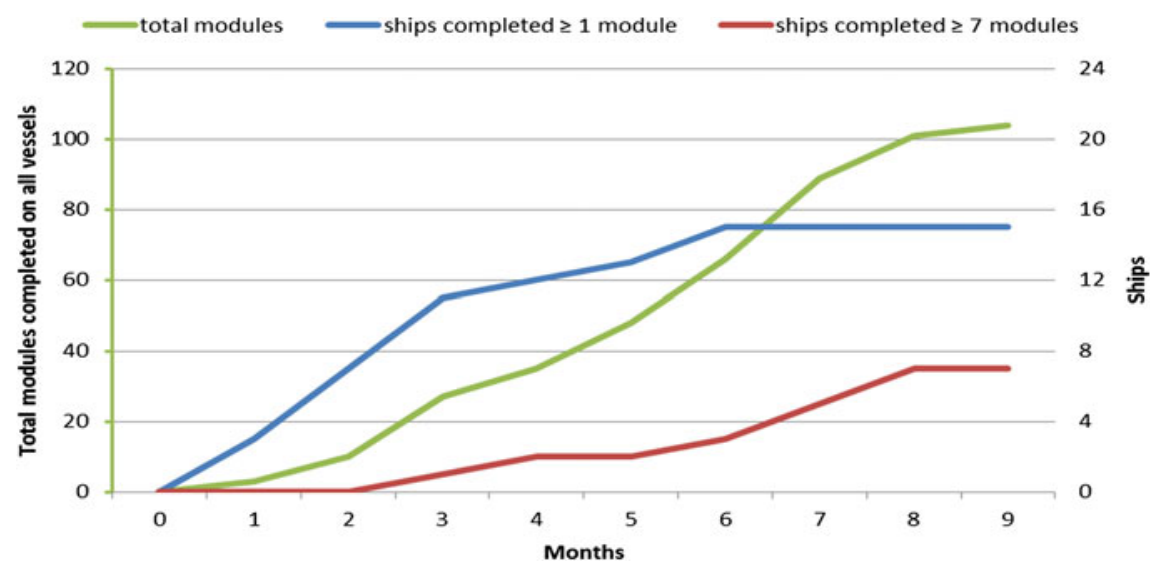

Fig. 1 Completion of the Shell resilience modules across 21 pilot ships 
all participate with such enthusiasm and zest. Good to see all appreciating one another. Great fun".

Despite an initially slow uptake, adoption of modules gradually increased over a 9-month period, with a plateau reached after 7 months. At this time, $71 \%$ of the ships had embarked on the programme, with one-third completing more than half of the modules (see Fig. 1). Ships were encouraged to continue with the resilience programme through monthly communications between the onshore office and the ships.

\section{Positive Psychology and Well-Being at Sea}

Seafaring has long combined paradoxes, such as social exclusion and continuous social proximity, confinement in open spaces, and multiculturalism, within the single organizational culture of a ship. Consistencies - such as social isolation and confinement with shipmates - are evident in onboard working and living conditions from the earliest seafarers to their contemporaries; nonetheless, substantial social changes are apparent in recent times, including the large-scale introduction of multinational crews, a revolution in information and communication technologies, and faster ship turnaround in ports (Alderton et al. 2004). Moreover, the tasks of ships' officers and crew are increasing, including operating ships' machinery and equipment and ensuring effective functioning of ships' machines and devices (Borodina 2013).

In light of research indicating that mariners are a professional group amongst those at the highest risk for stress (Lipowski et al. 2014) and associated mental health conditions (Jezewska et al. 2006), researchers are calling for the psychological health of seafarers to be adequately investigated, measured, and addressed (Carotenuto et al. 2013). As suggested by Oldenburg and colleagues, there is a substantial need for research to assess the complex life and work situation of seafarers while on board (Oldenburg et al. 2013). In particular, more research on psychosocial aspects of mariners' health is required (MacLachlan et al. 2012). For decades, a collective focus of the fields of psychology, neuroscience and mental health on the long- and short-term consequences of stress is evident, and, more recently, on extreme stress (Southwick et al. 2014). As highlighted by Schager, the shipping industry could gain many benefits by availing of modern scientific psychology (Schager 1997).

This chapter explores positive psychology as an approach to enhancing well-being at sea. To date, the application of positive psychology concepts, interventions and training to the maritime context has been explored only to a limited degree. This chapter commences with a discussion of the seafaring context. The ship as an isolated and confined environment, a safety-critical organization, and as a fusion of maritime-specific stressors is considered. Next, the field of positive psychology - its conception and previous applications-is discussed. Along these 
lines, the field of positive organizational psychology and the newly emerging field of positive organizational behaviour are explored, with a particular focus on psychological capital, including resilience, as a core construct of positive organizational behaviour. Ensuing these sections is a discussion of the contexts in which positive psychology has previously been applied to promote well-being at sea. To conclude, rationale for future research and key research questions are presented.

\section{Seafaring Environment}

Improvements in the life of seafarers are evident, with modern ships frequently being clean and comfortable (Hult 2012a), although it is recognized that accommodation standards vary substantially between ships (Alderton et al. 2004). The living conditions of seafarers have some notable advantages, including long periods of time off, variety, a sense of belonging on board, and a feeling of having acquired good skills (Hult 2012a). As proposed by Leszczynska et al., although there is substantial diversity in standards across national fleets, systematic improvements in the maritime work environment have been occurring for some years, including increased comfort; reduction of exposure to harmful physical, chemical and biological hazards; moderation of noise and vibration; installation of air-conditioning; and increases in living space in the form of single cabins (Leszczynska et al. 2007).

Nonetheless, seafaring continues to be associated with a multitude of mental, psychosocial, and physical stressors, which include authoritative leadership, heavy mental and physical workload, long work hours, lack of exercise and often unhealthy diets (Comperatore et al. 2005), separation from family, loneliness on board, fatigue, sleep deprivation, multi-nationalities, restricted recreation opportunities (Carotenuto et al. 2012), and environmental stressors including ship motion, noise and vibration, perceived as stressful particularly during sleeping times (Oldenburg et al. 2010). In a study conducted by Oldenburg et al. comprising a sample of 134 male seafarers, interviewees reported the most significant stressors on board as separation from their family, time pressure, long working days, heat in workplaces, and insufficient qualifications of subordinate crew (Oldenburg et al. 2009). Indeed, many stressors experienced by mariners may be chronic in nature (Lipowski et al. 2014).

As emphasized by Jezewska and colleagues, people working at sea experience stress related to their specific work conditions, significant job responsibilities and psychosocial factors, which produce health and psychological problems (Jezewska et al. 2006). In a study conducted with seafarers of the Danish merchant fleet, Haka and colleagues found that the majority of job demands and job resources perceived by the seafarers were psychosocial rather than organizational factors, such as interpersonal relationships with crew (Haka et al. 2011). The incidence of seafarer deaths through suicide suggests that the mental health of seafarers continues to be very poor, and there is a call to action to address this by those involved in the maritime shipping industry (Iversen 2012). While mortality studies have provided 
valid comparisons between the health of seafarers and that of the remainder of the population, a limitation of these studies is their omission of mental health conditions; indeed, the most common form of ill-health at sea on non-passenger vessels is mental health problems (Carter 2011a).

Increasing awareness of mental health problems at sea is apparent, associated with a variety of practical initiatives related to this area; for instance on ships and in docks, leaflets are increasingly made available for the purposes of providing access to mental health information and to address the strong stigma associated with mental health problems that is evident across cultures (MacLachlan et al. 2013). A significant stride forward is the Maritime Labour Convention 2006, widely known as the "Seafarers' Bill of Rights," which provides international seafaring standards, including health on board (International Labour Organization (ILO) 2013). According to the Maritime Labour Convention, consideration should be afforded to investigate "special physiological or psychological problems created by the shipboard environment" [Guideline B4.3.6(c)] and "problems arising from physical stress on board a ship" [Guideline B4.3.6(d)] (ILO 2006). Yet many seafarers may be reluctant to seek medical and psychological assistance as the physical demands and health requirements of seafaring are strict and the job market is seemingly competitive (Oldenburg et al. 2010).

As proposed by Carotenuto and colleagues, in light of the heightened risk of depression and suicide, the psychological ill-health of seafarers should be accurately investigated, measured, followed up and countered as far as possible (Carotenuto et al. 2013). Jezewska and colleagues have called for the training in psychological skills for seafarers as a preventative measure for stress, with the aim of developing interpersonal competence, particularly for the capacity of solving interpersonal conflicts on board, as well as providing and receiving support (Jezewska et al. 2006). In a survey of 78 Royal Australian Navy submariners, psychological distress at sea was found to be moderated by personal resources, including problem-solving skills, social support, involvement in recreational activities, and self-care behaviour (McDougall and Drummond 2010).

When designing interventions to mitigate stress and support seafarers' psychological well-being, it is important to recognize occupational, cultural and demographic factors that may influence how stress may be differentially experienced, expressed, and alleviated on board. For example, in a cross-sectional study of 685 engine room officers in the Swedish merchant fleet, Rydstedt and Lundh found that older engine officers reported significantly higher degrees of perceived stress compared to younger colleagues (Rydstedt and Lundh 2012). In relation to ranks of seafarers, Carotenuto and colleagues found that beyond stressors that represent the most prevalent sources of stress of seafarers, such as loneliness, leisure scarcity and fatigue, a number of specific features differentiate seafarers based on rank and job category. For instance, sleep disturbances are reported by pilots and engineers with higher incidence than by masters/mates and deck crew, although deck crew report the lowest job satisfaction levels (Carotenuto et al. 2012). Oldenburg et al. reported 
that officers stayed on board for considerably shorter periods than non-officers (4.8 vs. 8.3 months per year) but had significantly more often a substantially higher number of working hours, and Europeans had shorter stays on board in comparison to non-Europeans (4.9 vs. 9.9 months/year) (Oldenburg et al. 2009). As the maritime industry is a global business in which vessels are often manned from several different cultures (ILO 2015; Johnsen et al. 2012), strategies aimed at improving psychological well-being of seafarers require recognition of cultural diversity. For example, Nielsen and colleagues, with a sample of 541 seafarers from two Norwegian shipping companies, found that European and Filipino respondents differed regarding their experience of both the work environment and well-being. The researchers found that Filipino crew members experienced the work environment as more negative, with greater levels of harassment, laissez-faire leadership, and poor safety, although Filipinos also experienced stronger team cohesion and perceived their captains as more authentic (Nielsen et al. 2013).

\section{The Ship as an Isolated, Confined Environment}

A ship is an isolated, confined environment - comprising the people, settings, tasks, amenities, and routines to which seafarers may be exposed for weeks and sometimes months at a time. From this perspective, a ship is a "hole" in the water containing the complex work dynamics of a group working on a common task; it is also a "whole" in the water, encapsulating the crew's world occupationally, socially, and personally (MacLachlan et al. 2013). Seafarers are amongst the most isolated demographic occupational groups globally (Oldenburg et al. 2010). Dissimilar to many other occupations, seafarers are periodically at the workplace both during working and non-working hours, 24 hour per day (Hult 2012a).

Opportunities for communication of seafarers with family and friends on shore are frequently highly restricted. In a study conducted by Kahveci, findings indicated that a very small proportion of seafarers had access to the Internet while on board; onboard email access varied substantially with regard to hierarchical structure, quantity, privacy, cost, and freedom of access; restricted access to email facilities on board increased dependence of seafarers on satellite telephone communication, and the most significant barriers to communication on board included access to communication facilities and cost of communication (Kahveci 2011). In a qualitative study of 10 Greek-owned shipping companies, Progoulaki et al. reported that communication was highlighted amongst the most important services, although those services provided were either too limited or expensive for crew. More specifically, while telephone was reported as a highly expensive means of communication, it was also considered as the primary means of communication that connected crew with family and friends on shore. Moreover, although Internet access was present, its use was primarily for business, although seafarers could send a restricted number of emails to family (Progoulaki et al. 2013). 


\section{The Ship as a Safety-Critical Organization}

The ship may also be conceptualized as a safety-critical organization. Seafaring is a practical and challenging profession that requires fast and correct analyses of situations, as well as rapid, decisive action (Gekara et al. 2011). Safety-critical organizations are complex adaptive systems (Reiman et al. 2015), which operate in high hazard industries, such as aviation, oil and chemical industry organizations (Oedewald and Reiman 2007) and seafaring (Smedley et al. 2013; Wang 2008). Workers in safety-critical organizations such as the offshore oil and gas industry operate in perilous environments, with numerous technological, environmental, and human challenges, which present a significant potential for injuries, accidents, stress, and various adverse health outcomes (Hystad et al. 2014). Almost all jobs at sea are safety critical and therefore declines in performance as a result of any cause, including psychosocial ones, may put seafarers and their vessel at significant risk (Carter 2005). Research and interventions addressing psychosocial factors of seafaring may therefore be astute and important on the basis of seafarers' health, but also, crucially, on performance and safety grounds.

\section{Positive Psychology}

Positive psychology is "a science of positive subjective experience, positive individual traits, and positive institutions (which) promises to improve quality of life" and prevent pathologies (Seligman and Csikszentmihalyi 2000, p. 5). As proposed by Gable and Haidt (2005), when defined in these terms, positive psychology has a long history, dating back to James's (1902) writings on what he labelled "healthy mindedness" (James 1902), to Allport's literature on positive human characteristics (Allport 1955), to the advocacy of Maslow for the study of healthy people in 1968 (Maslow 1968). As offered by Maslow (1954):

\footnotetext{
The science of psychology has been far more successful on the negative than on the positive side. It has revealed to us much about man's shortcomings, his illnesses, his sins, but little about his potentialities, his virtues, his achievable aspirations, or his full psychological height. It is as if psychology has voluntarily restricted itself to only half its rightful jurisdiction, and that, the darker, meaner half (p. 354).
}

Indeed, contemporary focus on well-being, and its component attributes such as happiness, subjective appreciation of the values and quality of life, satisfaction and fulfilment, is far from new ground; contemplation of these subjects is traced back as far as ancient Socratic philosophy, and the vast majority of, if not all, religious and spiritual movements express concern and potential insight into the pursuit of happier and more meaningful lives (Gibbs and Burnett 2011). Aristotle believed that happiness (which he named "eudaimonia") was realized through knowing your true self and acting in line with your virtues, while Epicurus and the hedonists believed in achieving happiness through maximizing pleasure and minimizing pain 
(Harvard Medical School 2011). From this perspective, positive psychology is thousands of years old, dating back to ancient philosophers and religious leaders who discussed happiness, character values, and the good society (Diener 2009). In such light, positive psychology has a very long past, but (as formally named of 1998) a very short history (Peterson 2006). As proposed by Tugade et al. (2004):

For centuries, folk wisdom has promoted the idea that positive emotions are good for your health: "A good laugh makes you healthy" (Swedish proverb); "The joyfulness of man prolongeth his days" (Bible, Ecclesiasticus. 30:22); "Mirth and merriment ... bars a thousand harms and lengthens life" (Shakespeare). Oftentimes in science, empirical evidence emerges to refute anecdotal wisdom. In the case of positive emotions and health, however, accumulating evidence is providing empirical support for such folk theories (p. 1).

Positive psychology, a novel and influential school of thought, spearheaded by Martin Seligman, President of the American Psychological Association 1998, focuses on promoting the study of well-being, and is disputably considered as foremost and archetypal of positive, well-being-oriented organizational and academic movements (Gibbs and Burnett 2011). This new branch of psychology is primarily concerned with the scientific study of human strengths and happiness, and factors that promote well-being (Carr 2011). Positive psychology is an umbrella term for motivating and organizing research, application, and scholarship on virtues, strengths, excellence, thriving, flourishing, resilience, flow and optimal functioning more generally (Donaldson and Ko 2010).

Contrary to psychology's focus of the past half century on relieving mental disorders, positive psychology seeks to understand positive emotion, build strength and virtue, and support individuals in living what Aristotle termed the "good life" (Seligman 2013). As indicated by Peterson and Park, positive psychologists do not declare to have invented the "good life" or to have propelled it into scientific study; rather, the contribution of positive psychology has been to provide an umbrella term for secluded branches of theory and research, and to assert that the "good life" deserves its own field of inquiry within psychology, at least until all of psychology comprises the study of what is "good" alongside what is "bad" (Peterson and Park 2003). From this perspective, a number of aphorisms underpin positive psychology: first, what is experienced as "good" in life is as genuine as what is experienced as "bad"-not secondary, illusory, or epiphenomenal; second, what is "good" in life is not simply the absence of what is "problematic"; and third, the "good life" necessitates its own explanation, and not simply an oblique or inverted theory of pathology (Peterson 2009). Accordingly, the aim of positive psychology is not to supersede research investigating psychological dysfunction or distress; rather, the aim is to cultivate and integrate knowledge of human resilience, strength, and opportunities to supplement and build on the existing knowledge base (Gable and Haidt 2005; Seligman et al. 2005).

Importantly, as emphasized by MacLachlan and Hand, positive psychology does not seek to eliminate painful emotions, which are frequently an entirely appropriate response to the reality of people's lives, and an integral part of the human experience. So, for example, while the loss of a loved one or personal injury may be 
justifiably experienced as difficult or painful, at the same time navigating these painful emotions can contribute to increased happiness and possibly reevaluation of one's life (MacLachlan and Hand 2013). As proposed by Seligman, contrary to the idea of positive psychology as a "creature of good times," the strengths that positive psychology seeks to cultivate may serve individuals throughout good times as well as more difficult times, for which the latter may be "uniquely suited to the display of many strengths" (Seligman 2013, p. 12).

In his influential book 'Authentic happiness', Seligman proposes that happiness can be analyzed in relation to three distinct components: first, positive emotionwhat we feel, such as pleasure, comfort, rapture, and ecstasy, which contribute to the "pleasant life"; second, engagement-signifying flow, such as being one with music, the experience of time stopping, and the loss of self-consciousness throughout an absorbing activity, experiences which contribute to the "engaged life"; and third, meaning - belonging to and serving something that you believe is bigger than you are, underpinning the "meaningful life" (Seligman 2013). Seligman's views have since shifted, however, from framing positive psychology as a branch of psychological science concerned with happiness and increasing life satisfaction through positive emotion, engagement, and meaning, to a focus on "well-being". According to Seligman, the benchmark for measuring well-being is "flourishing" and the goal of positive psychology is to increase flourishing. As proposed by this new well-being theory, flourishing rests on five pillars: positive emotion, engagement, meaning, accomplishment (or achievement), and relationships (Seligman 2011a).

Relationships, our key to the "connected life," are therefore a cornerstone of flourishing as proposed by Seligman's theory of well-being. As outlined by Seligman, when asked what, in two words or fewer, positive psychology is all about, its cofounder Christopher Peterson responded, "other people" (Seligman 2011b). As declared by Seligman, relationships with other people may be the most effective antidote to the "downs" of life and the single most dependable "up" (Seligman 2011b). As proposed by Haidt, "Happiness comes from between"some conditions necessary for happiness are within the person, such as coherence among the parts of their personality, while other conditions necessitate relationships to elements beyond the person, so there is a need for love, work, and connection to something larger; if a person gets these relationships right, a sense of purpose and meaning emerges (Haidt 2006). As emphasized by Carr, scientific research indicates three reliable ways to promote happiness: (1) cultivate relationships that comprise deep attachment and commitment; (2) partake in absorbing work and leisure activities in which you avail of your strengths, talents and interests; and (3) cultivate an optimistic, future-oriented perspective on life in which you expect the best to happen (Carr 2011).

In many ways, the core work of positive psychology is focused on the efficacy of psychological interventions to increase individual happiness (Seligman et al. 2005). Positive psychology interventions may be elucidated as intentional activities based on (a) cultivation of positive subjective experiences; (b) building of positive individual traits; or (c) building of civic virtue and positive institutions (Meyers et al. 2013). 
Examples comprise keeping a gratitude diary, counting acts of kindness towards others, and focusing on the good aspects of life (Thompson et al. 2014). Approximately 40 interventions purporting to increase long-term happiness have been collected and condensed into replicable and manualizable form by Seligman and colleagues, including "you at your best," whereby participants are asked to write about a time when they were at their best, to reflect on the personal strengths displayed in the story, and to review and reflect on the story once every day for 1 week; and "using signature strengths in a new way," whereby individuals are asked to avail of the inventory of character strengths online and to use one of their identified top strengths in a new way every day for 1 week (Seligman et al. 2005).

The application of positive psychology interventions has been explored across many diverse settings, including education (Shoshani and Steinmetz 2014; Waters 2011), such as the PENN Resiliency Program, a group intervention for school children (Penn Positive Psychology Center 2007); organizations (Bono et al. 2013; Meyers et al. 2013), including safety-critical organizations, such as the offshore oil industry (Hystad et al. 2014) and U.S. Army (Azar 2011); and clinical, including group interventions for breast cancer patients (Cerezo et al. 2014), interventions to reduce stress in people newly diagnosed with HIV (Tedlie Moskowitz et al. 2014), interventions to promote positive states and strengths of character for patients with or at risk of cardiac disease (Dubois et al. 2012), and psychotherapy (Schrank et al. 2014; Seligman et al. 2006).

A growing literature on such positive psychology interventions indicates that the "good life"- positive emotion, engagement, relationships, meaning, and accomplishment - can be strengthened (Seligman 2010). For example, in a meta-analytical study of the effectiveness of positive psychology interventions, Bolier and colleagues reported that positive psychology interventions significantly enhanced subjective and psychological well-being and reduced depressive symptoms (Bolier et al. 2013). In a six-group, randomized placebo-controlled Internet study, Seligman et al. found that two interventions-writing about three good things that happened each day and why they happened, and using signature strengths of character in a new way-made people happier (and less depressed) up to 6 months later (Seligman et al. 2005). As emphasized by Fredrickson, diverse interventions - including finding positive meaning, relaxation training, and invoking empathy or amusement - share the capacity to evoke positive emotions while lessening negative emotions (Fredrickson 2000). Importantly, evidence is accumulating that positive emotions are associated with beneficial psychological and physical health effects; positive emotions can be an important factor that safeguards individuals against maladaptive health outcomes (Tugade et al. 2004).

Contrary to studies such as those outlined above, there is research indicating that under certain circumstances overvaluing happiness may be less conducive to well-being. For example, Mauss et al. (2011) conducted two studies to explore paradoxical effects of valuing happiness. In their first study, female participants who valued happiness more reported lower happiness under conditions of low, but not high, life stress. In their second study, female participants who were induced experimentally to value happiness reacted less positively to a happy, but not a sad, 
emotion induction, when compared to a control group. Participants' disappointment by their own feelings mediated the effect. The researchers propose that valuing happiness may lead people to feel less happy in positive contexts when expectations for happiness are high (Mauss et al. 2011). As proposed by Ford and Mauss, first, as individuals pursue happiness, they typically set high standards for their happiness, which may create discontent and decrease happiness when their current state falls below such standards; second, individuals are not constantly accurate regarding what will assist them to achieve happiness, and may consequently engage in activities that are ineffective for increasing their happiness; and third, as individuals pursue happiness, they typically monitor their accomplishment of this goal, and such monitoring may reduce their ability to achieve happiness (Ford and Mauss 2014). Accordingly, activities to promote well-being may be more effective when aimed to direct participants' efforts on the specific activity, such as practicing acts of kindness, rather than on the sole value of increasing happiness (Nelson and Lyubomirsky 2012). Indeed, current perspectives of positive psychology assume a focus less on "positive" targets at shallow level, and more on what factors may lead to healthy well-being; in some cases, positive emotion and psychological strengths lead to suboptimal living, while emotions such as anxiety and confrontational behaviours may result in the best possible outcomes (Ciarrochi et al. 2013).

For whom, in what circumstances, and through which mechanisms positive psychology interventions work are largely person, activity, and context dependent. Importantly, positive psychology interventions therefore are required to consider individual differences (Azar 2011). Because individuals have diverse strengths, interests, values, and inclinations that allow them to benefit more from some strategies than others, no one particular activity will help all individuals to become happier (Lyubomirsky et al. 2005). In a study conducted by Brunstein et al. (1998), the researchers found that progress towards motive-congruent goals, in contrast to progress towards motive-incongruent goals, accounted for a sample of students' daily experiences of emotional well-being. Similarly, Fordyce (1977), in relation to a self-study programme designed to increase personal happiness and life satisfaction, reported that the particular components of the programme considered most happiness producing greatly varied between subjects, seemingly determined by individuals' needs and areas of particular weaknesses. In a study conducted by Wood and colleagues, among participants with low self-esteem, those who repeated a positive self-statement ("I'm a lovable person") felt worse than those with low self-esteem who did not repeat the statement; among participants with high self-esteem, those who repeated the statement felt better than those who did not, but only to a limited degree (Wood et al. 2009).

Similarly, Thompson and colleagues investigated how gender may affect self-reported person-activity fit across three positive psychology interventions: gratitude journal; acts of kindness; and savouring life's joys. The results indicated that gender influenced person-activity fit regarding the above interventions, with females in all cases reporting a higher fit than males (Thompson et al. 2014). Lyubomirsky and Layous have proposed the person-activity fit model, which presents: (a) an overview of the activity features and person features that render a 
positive activity optimally effective; and (b) the mechanisms that underlie the positive activity's successful improvement of well-being. The researchers propose that the degree to which an activity feature affects a positive activity's success is determined by the fit between the person, such as personality or culture, and that activity feature, such as dosage or social support (Lyubomirsky and Layous 2013).

\section{Positive Organizational Psychology}

Positive organizational psychology can be interpreted as the scientific study of positive subjective experiences and traits in the workplace and positive institutions (Donaldson and Ko 2010). Positive organizational psychology may be considered as an overarching term comprising the newly emerging fields of positive organizational scholarship (POS) and positive organizational behaviour (POB) (Donaldson and Ko 2010). POS focuses on the study of positive outcomes, processes, and attributes of organizations and their members (Cameron et al. 2003). Along similar lines, POB is concerned with the study of individual positive psychological conditions and human resource strengths that are related to employee well-being or performance improvement (Bakker and Schaufeli 2008), and such positive psychological conditions and human resource strengths that are "state-like" (Luthans et al. 2008), signifying that they are not fixed and are more easily changed than "trait-like" constructs.

While both POS and POB share the common origins of positive psychology, and are underpinned by the scientific process in the development of knowledge, POB differs from POS in a number of respects: POB primarily focuses on individual psychological qualities and their impact on performance improvement; its studies have been conducted chiefly at the micro and meso levels of analysis using survey research; and POB has tended to develop in an inductive way (i.e. from individual to group to organizational levels of analysis) (Donaldson and Ko 2010). Due to its principal focus on individual psychological qualities that are state-like and therefore more amenable to change, which aligns with the topic of this chapter, POB is discussed below in more detail.

Positive organizational behaviour. The recently developing field of POB follows the lead of positive psychology (Bakker and Schaufeli 2008; Youssef and Luthans 2007). POB is defined as "the study and application of positively oriented human resource strengths and psychological capacities that can be measured, developed, and effectively managed for performance improvement in today's workplace" (Luthans and Church 2002, p. 59). As suggested by this definition, the specific criteria to determine positive capacities include being based on theory and research with valid measurement, and also that such capacities are state-like, signifying, as outlined above, that the capacity must be malleable and open to change (Luthans et al. 2008).

An example of a recent POB study is one conducted by Youssef and Luthans, who tested the impact that positive psychological resource capacities of hope, 
optimism, and resilience had on work-related employee outcomes, including performance, job satisfaction, work happiness, and organizational commitment. Their findings generally supported their hypotheses that employees' positive psychological resource capacities related to, and contributed equal variance to, the outcomes (Youssef and Luthans 2007). Numerous other studies have shown that positive organizational phenomena can make a distinct contribution to explaining variance in organizational outcomes (Bakker and Schaufeli 2008). For example, Losada's observational study among 60 business teams tested the effect of positive versus negative speech on performance. Specifically, performance was evaluated using three indicators: profitability, customer satisfaction, and assessments of the team by their superiors, peers and subordinates. A speech act was coded as positive if the participant showed support, encouragement, or appreciation, and was coded as negative if the participant speaking showed sarcasm, disapproval or cynicism. Findings indicated that high-performance teams showed more positive speech, providing empirical support for positive speech among team members as distinguishing high-performance teams from less successfully performing teams (Losada 1999).

Psychological capital. Psychological capital is a core construct of POB (Luthans et al. 2006). Luthans et al. (2007a, b) define psychological capital as:

an individual's positive psychological state of development and is characterized by: (1) having confidence (self-efficacy) to take on and put in the necessary effort to succeed at challenging tasks; (2) making a positive attribution (optimism) about succeeding now and in the future; (3) persevering towards goals and, when necessary, redirecting paths to goals (hope) in order to succeed; and (4) when beset by problems and adversity, sustaining and bouncing back and even beyond (resiliency) to attain success (p. 3).

The term "psychological capital" in this sense signifies individual motivational propensities that accumulate through positive psychological constructs, including efficacy, optimism, hope and resilience (Luthans et al. 2007a, b). Psychological capital constructs are posited as being "state-like," although not momentary states (Luthans et al. 2007a, b).

Psychological capital may be an important factor concerning seafarers' safety climate. From a sample of seafarers working on oil platform supply ships, empirical support is provided by Hystad et al. for psychological capital as an important factor of safety climate (Hystad et al. 2014). Along similar lines, in two studies investigating the potential relationship between psychological capital and perceptions of safety climate among maritime workers from three Norwegian shipping companies, Bergheim et al. reported that psychological capital, including resiliency, was positively associated with perceptions of safety climate (Bergheim et al. 2015).

Resilience. Resilience may be defined as the ability to "bounce back" from adversity (Luthans et al. 2006). Resilience has been conceptualized as the capacity to maintain healthy functioning despite increased stressors, and to recover to full functioning following a demanding period (Stanley et al. 2011). The American Psychological Association (APA) outlines ten ways to build resilience: (1) Make connections; (2) Avoid seeing crises as insurmountable problems; (3) Accept that 
change is a part of living; (4) Move towards your goals; (5) Take decisive actions; (6) Look for opportunities for self-discovery; (7) Nurture a positive view of yourself; (8) Keep things in perspective; (9) Maintain a hopeful outlook; and (10) Take care of yourself (American Psychological Association 2015).

Research shows that resilience has a positive relationship with recovery from daily stressors. Ong et al. found that psychological resilience accounted for meaningful differences in emotional responses to daily stressors. Their findings indicated that, over time, the experience of positive emotions may function to assist high-resilient individuals in their capacity to recover effectively from daily stress (Ong et al. 2006). This link between positive emotions and resilience is supported by empirical research (Cohn et al. 2009). The Broaden-and-Build theory (Fredrickson 2001) postulates that experiences of positive emotions serve to build enduring personal resources-including physical, intellectual, social and psychological resources - and are a resource that can be used when individuals undergo stressful experiences. As proposed by Fredrickson, positive emotions, when effectively employed, can optimize psychological resilience, health, and subjective well-being (Fredrickson 2000). Positive emotions boost resilience, which in turn stimulates more positive feelings; in other words, positive emotions and resilience mutually reinforce each other (Smith and Hollinger-Smith 2015).

One possible path to resilience is personality hardiness, a characteristic sense that life is meaningful, that we choose our futures, and that change is interesting and valuable (Bartone 2006). Hardy attitudes and strategies may facilitate resilience under stress. Hardy attitudes are: (1) commitment, signifying the belief that no matter how difficult life gets, it is important to stay involved with whatever is happening rather than detaching and becoming alienated; (2) control, indicating the belief that no matter how difficult life becomes, there is a need to continue trying to turn the stresses from potential disasters into growth opportunities, rather than sinking into powerlessness and passivity; and (3) challenge, the view that stressful changes are opportunities to grow in wisdom and capability (Maddi 2013). Alongside commitment, control and challenge, the hardy-resilient style individual shows a strong future orientation - an inclination to look optimistically towards the future while learning from the past (Bartone et al. 2012).

According to Bartone, while the underlying mechanisms of how hardiness may increase resilience regarding stress are not yet fully understood, a significant aspect of the hardiness-resilience mechanism may involve the meaning that individuals attach to events. From this perspective, individuals high in hardiness characteristically interpret experiences as largely interesting and worthwhile; over which they can exert control; as challenging; and as presenting opportunities to learn and grow (Bartone 2010). It is through this "shaping" of stressful experiences that leaders may foster hardy-resilient response patterns in a group setting, whereby a leader high in hardiness communicates a positive construction of shared stressful experiences, which may influence the entire group in the direction of a more positive interpretation of the experience (Bartone 2010, 2012).

Resilience from this standpoint may be fostered. As alluded to above, resilience is posited as not being trait-like in that individuals either have it or do not; rather, it 
comprises behaviours, thoughts and actions that can be learned and developed (APA 2015). Accordingly, training programmes that aim to develop or enhance resilience may be effective in improving health, well-being and quality of life (Leppin et al. 2014). As proposed by Hystad and Bye, a central aspect of hardiness training may be to assist people to change their mental models so that they may develop a broader perspective of life's circumstances and find alternative ways of understanding themselves and their experiences (Hystad and Bye 2013). Accordingly, resilience training may be conceptualized as providing techniques and a setting to reflect on one's way of thinking and to allow people to initiate changes to their thinking. According to a report of an International Maritime Health Association workshop (Carter 2005), research needs to focus on the resilience and coping strategies of seafarers, with interventions to modify these factors, and additional support and counselling in the early stages of identified distress.

\section{Positive Psychology and Well-Being at Sea}

MacLachlan and colleagues have called for the application of positive psychology in the maritime sector for the purposes of developing unique occupational health and performance programmes suitable to life on board. The researchers call on health and occupational practitioners in the maritime industry to more effectively utilize the characteristics of maritime work to develop intervention programmes that stimulate strengths, health and good performance of seafarers (MacLachlan et al. 2013). As proposed by organizational psychologists Gregory and Shanahan in their influential maritime guide 'The human element: A guide to human behaviour in the shipping industry', there are many practical things that can be done to ensure people work to their strengths (Gregory and Shanahan 2010). Table 1 outlines examples of commonly used interventions in positive psychology and their potential relevance to maritime health.

The familiar expression of "happy ship" suggests that job satisfaction may be a crucial element in maritime organizations (Bergheim et al. 2015). Yet, the application of positive psychology to the maritime context has been restricted primarily to resilience and "mindfulness" training. However, Van Wijk and Waters present a case study of the implementation of an interview model that focuses on strengths and positive health aspects, for the purposes of the annual psychological assessment of a group of naval specialists. In contrast to the traditional approach of a medical diagnostic interview, a significant difference was found in relation to post-assessment referrals for counselling, suggesting that this innovative positive psychology interview approach may have contributed to preventing later distress (van Wijk and Waters 2008).

Programmes aiming to enhance resilience of mariners are evident. For example, the U.S. Navy Operational Stress Control Programme aims to assist sailors to avoid stress injuries, recover from adverse situations and build resilience - to strengthen 
Table 1 Examples of commonly used positive psychology interventions

\begin{tabular}{|c|c|c|c|}
\hline Study & Intervention & Outcomes & $\begin{array}{l}\text { Relevance to Maritime } \\
\text { Health }\end{array}$ \\
\hline $\begin{array}{l}1 . \\
\text { Seligman } \\
\text { et al. } \\
(2005)\end{array}$ & $\begin{array}{l}\text { Three good things in life } \\
\text { - Participants were } \\
\text { asked to write down three } \\
\text { things that went well each } \\
\text { day and their causes } \\
\text { every night for } 1 \text { week }\end{array}$ & $\begin{array}{l}\text { At the 1-month follow } \\
\text { up, participants were } \\
\text { happier and less } \\
\text { depressed than they had } \\
\text { been at baseline, and } \\
\text { stayed happier and less } \\
\text { depressed at 3-month and } \\
\text { 6-month follow-ups }\end{array}$ & $\begin{array}{l}\text { Maritime workers may be } \\
\text { at heightened risk of } \\
\text { depression and suicide. } \\
\text { Positive psychology } \\
\text { interventions such as } \\
\text { "Three good things in } \\
\text { life" for seafarers may } \\
\text { facilitate increases in } \\
\text { happiness and decreases } \\
\text { in depressive symptoms } \\
\text { for up to } 6 \text { months }\end{array}$ \\
\hline $\begin{array}{l}2 . \\
\text { Luthans } \\
\text { et al. } \\
(2008)\end{array}$ & $\begin{array}{l}\text { Developing } \\
\text { psychological capital-A } \\
\text { highly focused, 2-hour } \\
\text { web-based training } \\
\text { intervention to develop } \\
\text { psychological capital, } \\
\text { including efficacy, hope, } \\
\text { optimism, and resilience. } \\
\text { A pretest, posttest } \\
\text { experimental design was } \\
\text { used ( } n=187 \text { were } \\
\text { randomly assigned to the } \\
\text { treatment group and } \\
n=177 \text { to the control } \\
\text { group) }\end{array}$ & $\begin{array}{l}\text { The treatment group } \\
\text { experienced a significant } \\
\text { increase in psychological } \\
\text { capital, while the control } \\
\text { group that participated in } \\
\text { a different but relevant } \\
\text { intervention did not show } \\
\text { a significant increase in } \\
\text { their psychological } \\
\text { capital }\end{array}$ & $\begin{array}{l}\text { Computer-based training } \\
\text { for seafarers on board and } \\
\text { on shore may provide an } \\
\text { effective approach for } \\
\text { programmes aiming to } \\
\text { enhance psychological } \\
\text { capital and well-being of } \\
\text { seafarers on a wider and } \\
\text { cost-effective scale }\end{array}$ \\
\hline $\begin{array}{l}\text { 3. Zeidan } \\
\text { et al. } \\
(2010)\end{array}$ & $\begin{array}{l}\text { Brief meditation training } \\
\text {-A study with a sample } \\
\text { of } 49 \text { university students } \\
\text { examining if the effects } \\
\text { of brief meditation } \\
\text { training can be found on } \\
\text { cognitive tasks with } \\
\text { varying demands on } \\
\text { working memory, } \\
\text { sustained attention, visual } \\
\text { coding, and verbal } \\
\text { fluency }\end{array}$ & $\begin{array}{l}\text { Brief training } \\
\text { significantly increased } \\
\text { mindfulness scores in } \\
\text { comparison to a control } \\
\text { group. The training } \\
\text { protocol had significant } \\
\text { effects on several } \\
\text { cognitive tasks that } \\
\text { require sustained } \\
\text { attention and executive } \\
\text { processing efficiency, e.g. } \\
\text { processing speed, } \\
\text { executive attention and } \\
\text { verbal fluency }\end{array}$ & $\begin{array}{l}\text { Mindfulness meditation } \\
\text { training may enhance } \\
\text { cognitive capacity of } \\
\text { maritime workers, such } \\
\text { as improved sustained } \\
\text { attention, the effect of } \\
\text { which may be enhanced } \\
\text { performance and safety in } \\
\text { maritime organizations }\end{array}$ \\
\hline $\begin{array}{l}\text { 4. King } \\
\text { (2001) }\end{array}$ & $\begin{array}{l}\text { Writing about life goals } \\
\text { - A sample of } 81 \\
\text { undergraduates wrote for } \\
20 \text { min each day for } \\
4 \text { days. Participants were } \\
\text { randomly assigned to }\end{array}$ & $\begin{array}{l}\text { Writing about life goals } \\
\text { was significantly less } \\
\text { upsetting than writing } \\
\text { about trauma and was } \\
\text { associated with a } \\
\text { significant increase in }\end{array}$ & $\begin{array}{l}\text { Writing about life goals } \\
\text { may generate health } \\
\text { benefits for maritime } \\
\text { workers such as increased } \\
\text { subjective well-being and } \\
\text { decreased illness. }\end{array}$ \\
\hline
\end{tabular}


Table 1 (continued)

\begin{tabular}{l|l|l|l}
\hline Study & Intervention & Outcomes & $\begin{array}{l}\text { Relevance to Maritime } \\
\text { Health }\end{array}$ \\
\hline & $\begin{array}{l}\text { write about their most } \\
\text { traumatic life event, their } \\
\text { best possible future self, } \\
\text { both of these topics, or a } \\
\text { non-emotional control } \\
\text { topic }\end{array}$ & $\begin{array}{l}\text { subjective well-being. } \\
\text { Five months after writing, } \\
\text { a significant interaction } \\
\text { emerged such that writing } \\
\text { about trauma, one's best } \\
\text { possible self, or both } \\
\text { were associated with } \\
\text { decreased illness } \\
\text { compared with controls }\end{array}$ & $\begin{array}{l}\text { Mental health is an } \\
\text { essential component of } \\
\text { productivity (WHO } \\
\text { Europe 2005). } \\
\text { Psychological } \\
\text { interventions that } \\
\text { increase subjective } \\
\text { well-being of maritime } \\
\text { workers may also } \\
\text { increase productivity of } \\
\text { maritime organizations }\end{array}$ \\
\hline $\begin{array}{l}\text { 5. } \\
\text { Peterson } \\
\text { et al. }\end{array}$ & $\begin{array}{l}\text { Using signature strengths } \\
\text { in a new way- } \\
\text { Participants were asked } \\
\text { to take an inventory of } \\
\text { character strengths online } \\
\text { and received } \\
\text { individualized } \\
\text { feedback about their top } \\
\text { five ("signature") } \\
\text { strengths. They were then } \\
\text { asked to use one of these } \\
\text { top strengths in a new } \\
\text { and different way every } \\
\text { day for 1 week }\end{array}$ & $\begin{array}{l}\text { Participants showed } \\
\text { increased happiness and } \\
\text { decreased depressive } \\
\text { symptoms for 6 months }\end{array}$ & $\begin{array}{l}\text { Positive psychology } \\
\text { interventions such as } \\
\text { identifying and using } \\
\text { one's signature strengths } \\
\text { may be an effective } \\
\text { approach to increasing } \\
\text { happiness and decreasing } \\
\text { depressive symptoms of } \\
\text { maritime workers }\end{array}$ \\
\hline
\end{tabular}

preparation to perform when confronting new challenges (U.S. Navy 2015). In non-military seafaring contexts, resiliency programmes are also apparent. As proposed by Greenberg, "Equipping mariners with the right psychologically focused skills and regular psychological monitoring can be effective methods of improving psychological resilience, detecting problems at an early stage, ensuring timely support and where necessary signposting to evidence based medical interventions" (March on Stress 2013). For example, as outlined above, peer-to-peer resilience training is currently being piloted by Shell Health (Jacobs 2013). Along similar lines, the SEAHORSE project comprises a consortium of 13 organizations from air and maritime transport sectors, with the overall aim of addressing "human factors and shipping safety." A primary goal of this project is to develop a multilevel resilience approach involving individuals, teams, multi-teams and organisations to ensure that interventions to strengthen resilience at one level have a positive effect on resilience at other levels (SEAHORSE project 2014).

Research is evident on the training of marines to cultivate the state-like quality of "mindfulness" - a moment-to-moment awareness of one's experiences, which has 
been shown to increase positive affect and decrease negative affect (Davis and Hayes 2012). Mindfulness fosters human characteristics that are central to positive psychology, including character strengths and virtues and psychological well-being, although it does so through acceptance-based rather than change-based approaches (Baer and Lykins 2011). In a study by Johnson and colleagues, marines who received Mindfulness-Based Mind Fitness Training (MMFT) showed inter alia enhanced recovery including heart rate and breathing rate after stressful training, signifying that mechanisms relating to stress recovery can be altered in healthy individuals prior to stress exposure (Johnson et al. 2014). Similarly, Stanley and colleagues found that marines who engaged more in MMFT practice showed greater self-reported mindfulness, associated with decreases in perceived stress (Stanley et al. 2011). Advantageous health effects of "mindfulness" training may also extend to mariners in the non-military context. Outlined in Table 2 are examples of interventions used in positive organizational psychology and their potential relevance to maritime health.

\section{Rationale for Future Research in the Area}

Due to the isolated and dispersed nature of the maritime context, online or computer-based positive psychology interventions and training may be a viable and important avenue of future research. Online positive psychology interventions have the capacity to empower people to manage their own well-being, while being highly accessible, low-cost, and scalable, reaching diverse types of populations (Bolier et al. 2014; Drozd et al. 2014; Redzic et al. 2014). Empirical support for the efficacy of online positive psychology interventions is provided by current research. For example, while Layous and colleagues found that a positive activity intervention significantly increased positive affect, no differences were found between participants who completed the positive activity online versus in person (Layous et al. 2013). Similarly, Luthans et al. found that the treatment group in a web-based training intervention to develop positive psychological capital, but not the control group, experienced a significant increase in their psychological capital (Luthans et al. 2008).

As proposed by Bergheim and colleagues, captains on board vessels are an important yet difficult group to include in a traditional management training programme, due to their prolonged time at sea, frequently in isolated environments, so that structured web-based or computer-based training programmes may be a valuable and cost-effective way to provide training opportunities during their off-duty hours on board (Bergheim et al. 2015). Of course, such interventions and training would need to be designed and administered with due cognizance of highly restricted Internet access of a large proportion of seafarers (Kahveci 2011; Progoulaki et al. 2013). However, positive psychology computer-based interventions and training, by which such programmes are readily accessible on computers 
Table 2 Examples of positive organizational psychology interventions

\begin{tabular}{|c|c|c|c|}
\hline Study & Intervention & Outcomes & $\begin{array}{l}\text { Relevance to Maritime } \\
\text { Health }\end{array}$ \\
\hline $\begin{array}{l}\text { 1. Hulsheger } \\
\text { et al. (2013) }\end{array}$ & $\begin{array}{l}\text { Mindfulness self-training- } \\
\text { Participants }(n=64) \text { were } \\
\text { randomly assigned to a } \\
\text { self-training mindfulness } \\
\text { intervention group/control } \\
\text { group. The sample } \\
\text { comprised various job } \\
\text { types, e.g. teachers, social } \\
\text { workers and bankers }\end{array}$ & $\begin{array}{l}\text { Participants in the } \\
\text { mindfulness intervention } \\
\text { group experienced } \\
\text { significantly more job } \\
\text { satisfaction than } \\
\text { participants in the control } \\
\text { group }\end{array}$ & $\begin{array}{l}\text { Job satisfaction is } \\
\text { considered a crucial } \\
\text { element in maritime } \\
\text { organizations (Bergheim } \\
\text { et al. 2015). Employees } \\
\text { who are more satisfied } \\
\text { with their work care } \\
\text { about the quality and } \\
\text { safety of their work, are } \\
\text { more committed to the } \\
\text { organization and more } \\
\text { productive (Håvold } \\
\text { 2007; Hult 2012b) }\end{array}$ \\
\hline $\begin{array}{l}\text { 2. Lambert } \\
\text { et al. (2012) }\end{array}$ & $\begin{array}{l}\text { Gratitude intervention- } \\
\text { Eight studies }(n=2973) \\
\text { testing the theory that } \\
\text { gratitude is related to fewer } \\
\text { depressive symptoms } \\
\text { through positive reframing } \\
\text { and positive emotion }\end{array}$ & $\begin{array}{l}\text { Results from these studies } \\
\text { indicate that gratitude is } \\
\text { related to fewer depressive } \\
\text { symptoms, with positive } \\
\text { reframing and positive } \\
\text { emotion serving as } \\
\text { mechanisms that account } \\
\text { for this relationship }\end{array}$ & $\begin{array}{l}\text { The most common form } \\
\text { of ill-health at sea on } \\
\text { non-passenger vessels is } \\
\text { mental health problems. } \\
\text { Positive psychology } \\
\text { training such as the } \\
\text { "Gratitude" intervention } \\
\text { may decrease depressive } \\
\text { symptoms of maritime } \\
\text { workers }\end{array}$ \\
\hline $\begin{array}{l}3 . \\
\text { Andersson } \\
\text { et al. (2007) }\end{array}$ & $\begin{array}{l}\text { Hope and gratitude } \\
\text { intervention-A } \\
\text { longitudinal study of } 308 \\
\text { white-collar U.S. } \\
\text { employees to assess effects } \\
\text { of feelings of hope and } \\
\text { gratitude on self-reported } \\
\text { concern for corporate social } \\
\text { responsibility }\end{array}$ & $\begin{array}{l}\text { Employees with stronger } \\
\text { hope and gratitude were } \\
\text { found to have a greater } \\
\text { sense of responsibility } \\
\text { towards employee and } \\
\text { societal issues, such as } \\
\text { social justice }\end{array}$ & $\begin{array}{l}\text { Interventions for } \\
\text { maritime workers to } \\
\text { increase feelings of } \\
\text { gratitude and hope may } \\
\text { increase sense of } \\
\text { responsibility toward } \\
\text { employee and societal } \\
\text { issues }\end{array}$ \\
\hline $\begin{array}{l}4 . \\
\text { Fredrickson } \\
\text { et al. (2008) }\end{array}$ & $\begin{array}{l}\text { Meditation practice-A } \\
\text { field experiment with } \\
\text { working adults }(n=139) \text {, } \\
\text { half of whom were } \\
\text { randomly assigned to begin } \\
\text { a practice of } \\
\text { loving-kindness meditation }\end{array}$ & $\begin{array}{l}\text { The meditation practice } \\
\text { produced increases over } \\
\text { time in daily experiences of } \\
\text { positive emotions, which } \\
\text { produced increases in } \\
\text { personal resources (e.g. } \\
\text { purpose in life, social } \\
\text { support, and decreased } \\
\text { illness symptoms). These } \\
\text { increases in personal } \\
\text { resources predicted } \\
\text { increased life satisfaction } \\
\text { and reduced depressive } \\
\text { symptoms }\end{array}$ & $\begin{array}{l}\text { The incidence of } \\
\text { seafarer deaths through } \\
\text { suicide suggests that the } \\
\text { mental health of } \\
\text { seafarers continues to be } \\
\text { very poor. Meditation } \\
\text { training of seafarers } \\
\text { could increase personal } \\
\text { resources, such as } \\
\text { purpose in life, which } \\
\text { may generate increased } \\
\text { life satisfaction and } \\
\text { decreased depressive } \\
\text { symptoms }\end{array}$ \\
\hline
\end{tabular}


Table 2 (continued)

\begin{tabular}{|c|c|c|c|}
\hline Study & Intervention & Outcomes & $\begin{array}{l}\text { Relevance to Maritime } \\
\text { Health }\end{array}$ \\
\hline $\begin{array}{l}\text { 5. Millear } \\
\text { et al. (2008) }\end{array}$ & $\begin{array}{l}\text { Resilience-building } \\
\text { programme-A pilot trial } \\
\text { of the Promoting } \\
\text { Adult Resilience } \\
\text { (PAR) programme, a } \\
\text { strengths-based } \\
\text { resilience-building } \\
\text { programme that integrates } \\
\text { interpersonal and } \\
\text { cognitive-behaviour } \\
\text { therapy. Pre, post and } \\
\text { follow-up measures on } 20 \\
\text { PAR participants from a } \\
\text { resource-sector company } \\
\text { were compared with a } \\
\text { non-intervention-matched } \\
\text { comparison group }\end{array}$ & $\begin{array}{l}\text { The PAR group maintained } \\
\text { significant post-test } \\
\text { improvements in coping } \\
\text { self-efficacy and lower } \\
\text { levels of stress and } \\
\text { depression. Process } \\
\text { evaluations of the PAR } \\
\text { programme showed that } \\
\text { skills were rated highly and } \\
\text { widely used in everyday } \\
\text { life at both post and } \\
\text { follow-up measurement } \\
\text { times }\end{array}$ & $\begin{array}{l}\text { People working at sea } \\
\text { may experience a } \\
\text { multitude of stressors. } \\
\text { Strengths-based } \\
\text { resilience-building } \\
\text { programmes may } \\
\text { enhance coping } \\
\text { self-efficacy and } \\
\text { decrease levels of stress } \\
\text { and depression of } \\
\text { maritime workers. } \\
\text { As mental health is an } \\
\text { essential component of } \\
\text { social cohesion (WHO } \\
\text { Europe } 2005 \text { ), } \\
\text { interventions to enhance } \\
\text { psychological } \\
\text { well-being of seafarers } \\
\text { may also strengthen } \\
\text { social cohesiveness of } \\
\text { employees of maritime } \\
\text { organizations }\end{array}$ \\
\hline
\end{tabular}

on board, may be a viable and judicious option for those aiming to increase positive psychological affect and capital of seafarers.

Effect duration and effect maintenance of positive psychology interventions are also pertinent areas of inquiry. As proposed by Seligman and Csikszentmihalyi, one fundamental gap of positive psychology relates to the relationship between momentary experiences of happiness and longer-lasting well-being (Seligman and Csikszentmihalyi 2000). However, studies indicating longer-term positive effects on well-being of positive psychology interventions are evident. For example, Cohn and Fredrickson found that many participants of a meditation intervention continued to meditate, to experience boosted positive emotions, and to maintain increased personal resources, more than one year after the end of training, signifying that skills-based positive psychology interventions may show longer-term effectiveness (Cohn and Fredrickson 2010). In relation to a self-administered "Three funny things" intervention in an online setting, Proyer et al. found that the intervention led to an increase in happiness and an amelioration of depressive symptoms at 6-months follow-up (Proyer et al. 2014). Similarly, Seligman and Steen reported two exercises - "Using signature strengths in a new way" and "Three good things"- that were found to increase happiness and decrease depressive symptoms of participants for 6 months (Seligman et al. 2005). 
A further promising line of inquiry relates to maritime health at the systems level. As emphasized by Carter, while the collection and analysis of information on seafarers' health is mostly addressed by health professionals, the use of such information is important for all areas of the maritime sector, and this introduces a variety of social, political, economic, regulatory, and ethical factors into all parts of the advancement of a knowledge base (Carter 2011b). Similarly, MacLachlan et al. propose that environmental, organizational, operational, safety, and cultural aspects all have an impact on maritime health; accordingly, the authors recommend a systems-based approach to research to facilitate the targeting and implementation of integrated health care interventions in the maritime environment (MacLachlan et al. 2012). A systems approach to managing stressors is the basis of the Crew Endurance Management System, extensively used in more recent times for implementing practices to control shipboard stressors (Comperatore et al. 2005; United States Coast Guard 2014). Along these lines, Comperatore and colleagues suggest that managing the complexity of shipboard stressors necessitates a systems approach that identifies individual elements in the complex system and determines how these elements are individually and collectively impacting on seafarers' endurance (Comperatore et al. 2005).

\section{Key Research Questions}

While recognizing that a range of questions may be proposed on the topic of positive psychology and well-being at sea, a number of selected research questions are presented below:

1. Do positive psychology interventions and training enhance well-being, performance and safety in the workplace, and through what mechanisms do these interventions and training operate? Are these mechanisms transferable to the maritime environment?

2. What are the facilitators and barriers to the effective implementation of positive psychology interventions that are specific to the maritime context?

3. Do positive psychology interventions show signs of effect maintenance in the maritime context?

4. Do positive psychology interventions present any advantages or disadvantages relative to other forms of psychological intervention in the maritime context?

5. How can positive psychology interventions and training be designed and administered to be accessible across ranks, sexes, ages, cultures and ethnicities on board?

6. Are positive psychology computer-based interventions and training an effective and viable option in the maritime context?

7. How can a systems-based approach to research and implementation be designed to facilitate integrated health care interventions in the maritime environment? 


\section{Conclusion}

While for centuries folk theory has promoted the concept that positive emotions are good for your health, accumulating empirical evidence is offering support for this anecdotal knowledge, indicating that positive emotions are associated with beneficial psychological and physical health effects (Tugade et al. 2004). Furthermore, a growing literature on positive psychology interventions suggests that the "good life"-positive emotion, engagement, relationships, meaning, and accomplishment — can be strengthened (Seligman 2010). The seafaring environment offers a unique context in which positive psychology interventions and training may be applied and tested. The isolated, confined, and safety-critical environment of the ship exposes seafarers to a very particular assortment of stressors. Conversely, as proposed by MacLachlan et al., this environment also offers unique opportunities to develop occupational health and performance programmes suitable to life on board, and the field of positive psychology may contribute in this respect due to its focus on facilitating positive health, attitudes and work behaviour, rather than on correcting for a "lack of," "failures," "errors" or "dysfunctions" (MacLachlan et al. 2013). Robust research is essential that shows scientifically the effects on well-being of positive psychology interventions administered on board. As proposed by Seligman, interventions that work are required, and a systematic programme of interventions that is scientifically proven to raise the level of human well-being (Seligman 2003).

Of course, as previously outlined, for whom, in what circumstances, and through which mechanisms positive psychology interventions work are largely dependent on the individual, activity, and context. As individuals have diverse strengths, interests, values, and inclinations that allow them to benefit more from some strategies than others, no one particular activity will help all individuals to become happier (Lyubomirsky et al. 2005). Moreover, interventions to mitigate stress and support seafarers' well-being should recognize the occupational, cultural and demographic factors that may influence how stress may be differentially experienced, expressed and alleviated on board.

To date, the application of positive psychology interventions and training to the maritime context has been examined only marginally - although research on "mindfulness" techniques and resilience training is evident in the navy and broader seafaring setting. As proposed by Progoulaki and colleagues, shipping companies are seemingly willing to invest in the well-being of seafarers as it is considered a primary source of productivity (Progoulaki et al. 2013). Whether the emergent focus of maritime organizations on supporting seafarers' well-being is health or productivity motivated, or both, an increasing awareness of mental health problems at sea is evident, associated with a variety of practical initiatives in this area. Importantly, however, as proposed by MacLachlan et al. (2012), a systems-based perspective that addresses safety, cultural, environmental, operational and organizational aspects can ensure a more comprehensive approach to maritime health. 


\section{References}

Alderton, T., Bloor, M., Kahveci, E., Lane, T., Sampson, H., Thomas, M. ... Zhao, M. (2004). The global seafarer: Living and working conditions in a globalized industry. Geneva: International Labour Office, Cardiff, UK: Seafarers International Research Centre.

Allport, G. W. (1955). Becoming: Basic considerations for a psychology of personality. New Haven: Yale University Press.

American Psychological Assocation. (2015). The road to resilience. Retrieved from http://www. apa.org/helpcenter/road-resilience.aspx

Andersson, L., Giacalone, R., \& Jurkiewicz, C. (2007). On the relationship of hope and gratitude to corporate social responsibility. Journal of Business Ethics, 70(4), 401-409. doi:10.1007/ s10551-006-9118-1

Azar, B. (2011). Positive psychology advances, with growing pains. Retrieved from http://www. apa.org/monitor/2011/04/positive-psychology.aspx

Baer, R. A., \& Lykins, E. L. B. (2011). Mindfulness and positive psychological functioning. In K. M. Sheldon, T. B. Kashdan, \& M. F. Steger (Eds.), Designing positive psychology: Taking stock and moving forward (pp. 335-348). New York: Oxford University Press Inc.

Bakker, A. B., \& Schaufeli, W. B. (2008). Positive organizational behavior: Engaged employees in flourishing organizations. Journal of Organizational Behavior, 29(2), 147-154. doi:10.1002/ job.515

Bartone, P. T. (2006). Resilience under military operational stress: Can leaders influence hardiness? Military Psychology, 18(Suppl), S131-S148. doi:10.1207/s15327876mp1803s_10.

Bartone, P. (2010). Forging stress resilience: Building psychological hardiness. In R. E. Armstrong, M. D. Drapeau, C. A. Loeb, \& J. J. Valdes (Eds.), Bio-inspired innovation and national security (pp. 243-255). Washington, D. C.: NDU Press.

Bartone, P. T. (2012). Social and organizational influences on psychological hardiness: How leaders can increase stress resilience. Security Informatics, 1(21), 1-10. doi:10.1186/2190$8532-1-21$

Bartone, P. T., Hystad, S. W., Eid, J., \& Brevik, J. I. (2012). Psychological hardiness and coping style as risk/resilience factors for alcohol abuse. Military Medicine, 177(5), 517-524.

Bergheim, K., Nielsen, M. B., Mearns, K., \& Eid, J. (2015). The relationship between psychological capital, job satisfaction, and safety perceptions in the maritime industry. Safety Science, 74, 27-36. doi:10.1016/j.ssci.2014.11.024

Bolier, L., Haverman, M., Westerhof, G. J., Riper, H., Smit, F., \& Bohlmeijer, E. (2013). Positive psychology interventions: A meta-analysis of randomized controlled studies. BMC Public Health, 13(119), 1-20. doi:10.1186/1471-2458-13-119

Bolier, L., Majo, C., Smit, F., Westerhof, G. J., Haverman, M., Walburg, J. A., et al. (2014). Cost-effectiveness of online positive psychology: Randomized controlled trial. The Journal of Positive Psychology, 9(5), 460-471. doi:10.1080/17439760.2014.910829

Bono, J. E., Glomb, T. M., Shen, W., Kim, E., \& Koch, A. J. (2013). Building positive resources: Effects of positive events and positive reflection on work stress and health. Academy of Management Journal, 56(6), 1601-1627. doi:10.5465/amj.2011.0272

Borodina, N. V. (2013). Use of sail training ship in seafarers' professional education. Asia-Pacific Journal of Marine Science \& Education, 3(1), 87-96.

Brunstein, J. C., Schultheiss, O. C., \& Grassmann, R. (1998). Personal goals and emotional well-being: The moderating role of motive dispositions. Journal of Personality and Social Psychology, 75(2), 494-508.

Cameron, K. S., Dutton, J. E., \& Quinn, R. E. (2003). Foundations of positive organizational scholarship. In K. S. Cameron, J. E. Dutton, \& R. E. Quinn (Eds.), Positive organizational scholarship: Foundations of a new discipline (pp. 3-13). San Francisco, California: Berrett-Koehler Publishers Inc. 
Carotenuto, A., Fasanaro, A. M., Molino, I., Sibilio, F., Saturnino, A., Traini, E., et al. (2013). The Psychological General Well-Being Index (PGWBI) for assessing stress of seafarers on board merchant ships. International Maritime Health, 64(4), 215-220.

Carotenuto, A., Molino, I., Fasanaro, A. M., \& Amenta, F. (2012). Psychological stress in seafarers: A review. International Maritime Health, 63(4), 188-194.

Carr, A. (2011). Positive psychology: The science of happiness and human strengths (2nd ed.). East Sussex, UK: Routledge.

Carter, T. (2005). Working at sea and psychosocial health problems: Report of an International Maritime Health Association Workshop. Travel Medicine and Infectious Disease, 3(2), 61-65. doi:10.1016/j.tmaid.2004.09.005

Carter, T. (2011a). Mapping the knowledge base for maritime health: 3 illness and injury in seafarers. International Maritime Health, 62(4), 224-240.

Carter, T. (2011b). Mapping the knowledge base for maritime health: 2. a framework for analysis. International Maritime Health, 62(4), 217-223.

Cerezo, M. V., Ortiz-Tallo, M., Cardenal, V., \& De La Torre-Luque, A. (2014). Positive psychology group intervention for breast cancer patients: A randomised trial. Psychological Reports, 115(1), 44-64. doi:10.2466/15.20.PR0.115c17z7

Ciarrochi, J., Kashdan, T. B., \& Harris, R. (2013). The foundations of flourishing. In T. B. Kashdan \& J. Ciarrochi (Eds.), Mindfulness, acceptance, and positive psychology (pp. 1-29). Oakland, CA.: Context Press.

Cohn, M. A., \& Fredrickson, B. L. (2010). In search of durable positive psychology interventions: Predictors and consequences of long-term positive behavior change. The Journal of Positive Psychology, 5(5), 355-366. doi:10.1080/17439760.2010.508883

Cohn, M. A., Fredrickson, B. L., Brown, S. L., Mikels, J. A., \& Conway, A. M. (2009). Happiness unpacked: Positive emotions increase life satisfaction by building resilience. Emotion, 9(3), 361-368. doi:10.1037/a0015952

Comperatore, C. A., Rivera, P. K., \& Kingsley, L. (2005). Enduring the shipboard stressor complex: A systems approach. Aviation, Space and Environmental Medicine, 76(6 Suppl), B108-B118.

Davis, D. M., \& Hayes, J. A. (2012). What are the benefits of mindfulness. Retrieved from http:// www.apa.org/monitor/2012/07-08/ce-corner.aspx

Diener, E. (2009). Positive psychology: Past, present and future. In S. J. Lopez \& C. R. Snyder (Eds.), The Oxford handbook of positive psychology (2nd ed.). New York: Oxford University Press Inc.

Donaldson, S. I., \& Ko, L. (2010). Positive organizational psychology, behavior, and scholarship: A review of the emerging literature and evidence base. The Journal of Positive Psychology, 5 (3), 177-191. doi:10.1080/17439761003790930

Drozd, F., Mork, L., Nielsen, B., Raeder, S., \& Bjørkli, C. A. (2014). Better Days-A randomized controlled trial of an internet-based positive psychology intervention. The Journal of Positive Psychology, 9(5), 377-388. doi:10.1080/17439760.2014.910822

Dubois, C. M., Beach, S. R., Kashdan, T. B., Nyer, M. B., Park, E. R., Celano, C. M., et al. (2012). Positive psychological attributes and cardiac outcomes: Associations, mechanisms, and interventions. Psychosomatics, 53(4), 303-318. doi:10.1016/j.psym.2012.04.004

Ford, B. Q., \& Mauss, I. B. (2014). The paradoxical effects of pursuing positive emotion: When and why wanting to feel happy backfires. In J. Gruber \& J. Moskowitz (Eds.), Positive emotion: Integrating the light sides and dark sides (pp. 363-381). New York: Oxford University Press.

Fordyce, M. W. (1977). Development of a program to increase personal happiness. Journal of Counseling Psychology, 24(6), 511-521. doi:10.1037/0022-0167.24.6.511

Fredrickson, B. L. (2000). Cultivating positive emotions to optimize health and well-being. Prevention \& Treatment, 3(Article 0001a).

Fredrickson, B. L. (2001). The role of positive emotions in positive psychology. The broaden-and-build theory of positive emotions. American Psychologist, 56(3), 218-226. 
Fredrickson, B. L., Cohn, M. A., Coffey, K. A., Pek, J., \& Finkel, S. M. (2008). Open hearts build lives: Positive emotions, induced through loving-kindness meditation, build consequential personal resources. Journal of Personality and Social Psychology, 95(5), 1045-1062. doi:10. $1037 / \mathrm{a} 0013262$

Gable, S. L., \& Haidt, J. (2005). What (and why) is positive psychology? Review of General Psychology, 9(2), 103-110. doi:10.1037/1089-2680.9.2.103

Gekara, V. O., Bloor, M., \& Sampson, H. (2011). Computer-based assessment in safety-critical industries: The case of shipping. Journal of Vocational Education \& Training, 63(1), 87-100. doi:10.1080/13636820.2010.536850

Gibbs, P. C., \& Burnett, S. B. (2011). Well-being at work, a new way of doing things? A journey through yesterday, today and tomorrow. In A. S. Antoniou \& C. Cooper (Eds.), New directions in organizational psychology and behavioral medicine (pp. 25-42). Surrey, UK: Gower Publishing Ltd.

Gregory, D., \& Shanahan, P. (2010). The human element: A guide to human behaviour in the shipping industry. London: The Stationary Office (TSO).

Haidt, J. (2006). The happiness hypothesis: Putting ancient wisdom and philosophy to the test of modern science. London, UK: Arrow Books.

Haka, M., Borch, D. F., Jensen, C., \& Leppin, A. (2011). Should I stay or should I go? Motivational profiles of Danish seafaring officers and non-officers. International Maritime Health, 62(1), 20-30.

Harvard Medical School. (2011). Positive psychology special health report. Boston, MA, U. S.: Harvard Health Publications, Harvard Medical School.

Håvold, J. I. (2007). From safety culture to safety orientation: Developing a tool to measure safety in shipping (Doctoral thesis). Norwegian University of Science and Technology, Norway. Retrieved from http://brage.bibsys.no/xmlui/handle/11250/265609

Hulsheger, U. R., Alberts, H. J., Feinholdt, A., \& Lang, J. W. (2013). Benefits of mindfulness at work: The role of mindfulness in emotion regulation, emotional exhaustion, and job satisfaction. Journal of Applied Psychology, 98(2), 310-325. doi:10.1037/a0031313

Hult, C. (2012a). Swedish seafaring life in 2009-2010. In C. Hult (Ed.), Swedish seafarers and seafaring occupation 2010: A study of work-related attitudes during different stages of life at sea (pp. 9-22). Kalmar, Sweden: Kalmar Maritime Acadamy.

Hult, C. (2012b). Work, motivation, and commitment. In C. Hult (Ed.), Swedish seafarers and seafaring occupation 2010: A study of work-related attitudes during different stages of life at sea (pp. 31-50). Kalmar, Sweden: Kalmar Maritime Academy.

Hystad, S. W., Bartone, P. T., \& Eid, J. (2014). Positive organizational behavior and safety in the offshore oil industry: Exploring the determinants of positive safety climate. Journal of Positive Psychology, 9(1), 42-53. doi:10.1080/17439760.2013.831467

Hystad, S. W., \& Bye, H. H. (2013). Safety behaviours at sea: The role of personal values and personality hardiness. Safety Science, 57, 19-26. doi:10.1016/j.ssci.2013.01.018

International Labour Organization. (2006). Maritime Labour Convention. Retrieved from http:// www.ilo.org/wcmsp5/groups/public/@ed_norm/@normes/documents/normativeinstrument/ wcms_090250.pdf

International Labour Organization. (2013). Basic facts on the Maritime Labour Convention 2006. Retrieved from http://www.ilo.org/global/standards/maritime-labour-convention/what-it-does/ WCMS_219665/lang-en/index.htm

International Labour Organization. (2015). International Labour Standards on Seafarers. Retrieved from http://ilo.org/global/standards/subjects-covered-by-international-labour-standards/seafarers/ lang-en/index.htm

Iversen, R. T. (2012). The mental health of seafarers. International Maritime Health, 63(2), 78-89.

Jacobs, K. (2013). Focus on 'resilience' to improve wellbeing, says Shell's health chief. Retrieved from http://www.hrmagazine.co.uk/hro/news/1140491/focus-resilience-improve-wellbeingshells-health-chief

James, W. (1902). The varieties of religious experience: A study in human nature. New York: Longmans, Green \& Co. 
Jezewska, M., Leszczynska, I., \& Jaremin, B. (2006). Work-related stress at sea self estimation by maritime students and officers. International Maritime Health, 57(1-4), 66-75.

Johnsen, B. H., Meeus, P., Meling, J., Rogde, T., Eid, J., Esepevik, R., et al. (2012). Cultural differences in emotional intelligence among top officers on board merchant ships. International Maritime Health, 63(2), 90-95.

Johnson, D. C., Thom, N. J., Stanley, E. A., Haase, L., Simmons, A. N., Shih, P. B., et al. (2014). Modifying resilience mechanisms in at-risk individuals: A controlled study of mindfulness training in marines preparing for deployment. American Journal of Psychiatry, 171(8), 844-853. doi:10.1176/appi.ajp.2014.13040502

Kahveci, E. (2011). Seafarers and communication. London, UK: ITF Seafarers' Trust. Retrieved from http://workinglives.org/fms/MRSite/Research/wlri/WORKS/Seafarers\%20and\%20Communication \%20Report.pdf

King, L. A. (2001). The health benefits of writing about life goals. Personality and Social Psychology Bulletin, 27(7). doi:10.1177/0146167201277003

Lambert, N. M., Fincham, F. D., \& Stillman, T. F. (2012). Gratitude and depressive symptoms: The role of positive reframing and positive emotion. Cognition \& Emotion, 26(4), 615-633. doi:10.1080/02699931.2011.595393

Layous, K., Nelson, S. K., \& Lyubomirsky, S. (2013). What is the optimal way to deliver a positive activity intervention? The case of writing about one's best possible selves. Journal of Happiness Studies, 14(2), 635-654. doi:10.1007/s10902-012-9346-2

Leppin, A. L., Gionfriddo, M. R., Sood, A., Montori, V. M., Erwin, P. J., Zeballos-Palacios, C. ... Tilburt, J. C. (2014). The efficacy of resilience training programs: A systematic review protocol. Systematic Reviews, 3(20). doi:10.1186/2046-4053-3-20

Leszczynska, I., Jaremin, B., \& Jezewska, M. (2007). Strategies towards health protection in maritime work environment involving the role of health promotion-Invitation to join in discussion. International Maritime Health, 58(1-4), 185-194.

Lipowski, M., Lipowska, M., Peplinska, A., \& Jezewska, M. (2014). Personality determinants of health behaviours of merchant navy officers. International Maritime Health, 65(3), 158-165. doi:10.5603/imh.2014.0030

Losada, M. (1999). The complex dynamics of high performance teams. Mathematical and Computer Modelling, 30(9-10), 179-192. doi:10.1016/S0895-7177(99)00189-2

Luthans, F., Avey, J. B., \& Patera, J. L. (2008). Experimental analysis of a web-based training intervention to develop positive psychological capital. Academy of Management Learning \& Education, 7(2), 209-221. doi:10.5465/AMLE.2008.32712618

Luthans, F., Avolio, B. J., Avey, J. B., \& Norman, S. M. (2007a). Positive psychological capital: Measurement and relationship with performance and satisfaction. Personnel Psychology, 60 (3), 541-572. doi:10.1111/j.1744-6570.2007.00083

Luthans, F., \& Church, A. H. (2002). Positive organizational behavior: Developing and managing psychological strengths [and executive commentary]. The Academy of Management Executive, 16(1), 57-75.

Luthans, F., Vogelgesang, G. R., \& Lester, P. B. (2006). Developing the psychological capital of resiliency. Human Resource Development Review, 5(1), 25-44. doi:10.1177/ 1534484305285335

Luthans, F., Youssef, C. M., \& Avolio, B. J. (2007b). Psychological capital: Developing the human competitive edge. New York: Oxford University Press.

Lyubomirsky, S., \& Layous, K. (2013). How do simple positive activities increase well-being? Current Directions in Psychological Science, 22(1), 57-62. doi:10.1177/0963721412469809

Lyubomirsky, S., Sheldon, K. M., \& Schkade, D. (2005). Pursuing happiness: The architecture of sustainable change. Review of General Psychology, 9(2), 111-131. doi:10.1037/1089-2680.9. 2.111

MacLachlan, M., Cromie, S., Liston, P., Kavanagh, B., \& Kay, A. (2013). Psychosocial and organisational aspects. In A. Schreiner (Ed.), Textbook of maritime medicine. Retrieved from: http://textbook.ncmm.no/ 
MacLachlan, M., \& Hand, K. (2013). Happy nation? Prospects for psychological prosperity in Ireland. Dublin, Ireland: The Liffey Press Ltd.

MacLachlan, M., Kavanagh, B., \& Kay, A. (2012). Maritime health: A review with suggestions for research. International Maritime Health, 63(1), 1-6.

Maddi, S. R. (2013). Hardiness: Turning stressful circumstances into resilient growth. New York: Springer.

March on Stress. (2013). March on stress news: Supporting occupational mental health in the shipping industry. Retrieved from http://www.marchonstress.com/index.php/news/article/73

Maslow, A. H. (1954). Motivation and personality. New York: Harper.

Maslow, A. H. (1968). Toward a psychology of being. New York: D. Van Nostrand Company.

Mauss, I. B., Tamir, M., Anderson, C. L., \& Savino, N. S. (2011). Can seeking happiness make people happy? Paradoxical effects of valuing happiness. Emotion, 11(4), 807-815. doi:10. 1037/a0022010

McDougall, L., \& Drummond, P. D. (2010). Personal resources moderate the relationship between work stress and psychological strain of submariners. Military Psychology (Taylor \& Francis Ltd), 22(4), 385-398. doi:10.1080/08995605.2010.513231

Meyers, M. C., van Woerkom, M., \& Bakker, A. B. (2013). The added value of the positive: A literature review of positive psychology interventions in organizations. European Journal of Work and Organizational Psychology, 22(5), 618-632. doi:10.1080/1359432X.2012.694689

Millear, P., Liossis, P., Shochet, I. M., Biggs, H., \& Donald, M. (2008). Being on PAR: Outcomes of a pilot trial to improve mental health and wellbeing in the workplace with the Promoting Adult Resilience (PAR) program. Behaviour Change, 25(4), 215-228. doi:10.1375/bech.25.4. 215

Nelson, S. K., \& Lyubomirsky, S. (2012). Finding happiness: Tailoring positive activities for optimal well-being benefits. In M. Tugade, M. Shiota, \& L. Kirby (Eds.), Handbook of positive emotions (pp. 275-293). New York: Guilford.

Nielsen, M. B., Bergheim, K., \& Eid, J. (2013). Relationships between work environment factors and workers' well-being in the maritime industry. International Maritime Health, 64(2), 8088.

Oedewald, P., \& Reiman, T. (2007). Special characteristics of safety critical organizations: Work psychological perspective (VTT Publications 633). Finland: VTT Technical Research Centre of Finland. Retrieved from http://www2.vtt.fi/inf/pdf/publications/2007/P633.pdf

Oldenburg, M., Baur, X., \& Schlaich, C. (2010). Occupational risks and challenges of seafaring. Journal of Occupational Health, 52(5), 249-256.

Oldenburg, M., Hogan, B., \& Jensen, H. J. (2013). Systematic review of maritime field studies about stress and strain in seafaring. International Archives of Occupational and Environmental Health, 86(1), 1-15. doi:10.1007/s00420-012-0801-5

Oldenburg, M., Jensen, H. J., Latza, U., \& Baur, X. (2009). Seafaring stressors aboard merchant and passenger ships. International Journal of Public Health, 54(2), 96-105. doi:10.1007/ s00038-009-7067-z

Ong, A. D., Bergeman, C. S., Bisconti, T. L., \& Wallace, K. A. (2006). Psychological resilience, positive emotions, and successful adaptation to stress in later life. Journal of Personality and Social Psychology, 91(4), 730-749. doi:10.1037/0022-3514.91.4.730

Penn Positive Psychology Center. (2007). Resilience in children. Retrieved from http://www.ppc. sas.upenn.edu/prpsum.htm

Peterson, C. (2006). A primer in positive psychology. New York: Oxford University Press Inc.

Peterson, C. (2009). Foreword. In C. R. Snyder \& S. J. Lopez (Eds.), Oxford handbook of positive psychology (2nd ed.). New York: Oxford University Press Inc.

Peterson, C., \& Park, N. (2003). Positive psychology as the evenhanded positive psychologist views it. Psychological Inquiry, 14(2), 143-147. doi:10.2307/1449822

Peterson, C., Park, N., \& Seligman, M. E. P. (2005). Assessment of character strengths. In G. P. Koocher, J. C. Norcross, \& S. S. Hill III (Eds.), Psychologists' desk reference (2nd ed., pp. 93-98). New York: Oxford University Press. 
Progoulaki, M., Katradi, A., \& Theotokas, I. (2013). Developing and promoting seafarers' welfare under the Maritime Labour Convention: A research agenda. SPOUDAI Journal of Economics and Business, 63(3-4), 75-82.

Proyer, R. T., Gander, F., Wellenzohn, S., \& Ruch, W. (2014). Positive psychology interventions in people aged 50-79 years: Long-term effects of placebo-controlled online interventions on well-being and depression. Aging \& Mental Health, 18(8), 997-1005. doi:10.1080/13607863. 2014.899978

Redzic, N. M., Taylor, K., Chang, V., Trockel, M., Shorter, A., \& Taylor, C. B. (2014). An Internet-based positive psychology program: Strategies to improve effectiveness and engagement. The Journal of Positive Psychology, 9(6), 494-501. doi:10.1080/17439760.2014.936966

Reiman, T., Rollenhagen, C., Pietikäinen, E., \& Heikkilä, J. (2015). Principles of adaptive management in complex safety-critical organizations. Safety Science, 71, Part B(0), 80-92. doi:10.1016/j.ssci.2014.07.021

Rydstedt, L. W., \& Lundh, M. (2012). Work demands are related to mental health problems for older engine room officers. International Maritime Health, 63(4), 176-180.

Schager, B. (1997). Advantages of psychological assessment prior to employment and promotion. Halmstad, Sweden: Marine Profile. Retrieved from http://www.marine-profile.com/Articles. html

Schrank, B., Brownell, T., Tylee, A., \& Slade, M. (2014). Positive psychology: An approach to supporting recovery in mental illness. East Asian Archives of Psychiatry, 24(3), 95-103.

SEAHORSE project. (2014). SEAHORSE: The project. Retrieved from http://www. seahorseproject.eu/TheProject/tabid/4193/Default.aspx

Seligman, M. E. P. (2003). Authentic happiness: Testing positive interventions. Retrieved from https://www.authentichappiness.sas.upenn.edu/newsletters/authentichappiness/ testinginterventions

Seligman, M. E. P. (2010). Flourish: Positive psychology and positive interventions (Tanner lectures on human values, delivered at the University of Michigan). Retrieved from http:// tannerlectures.utah.edu/_documents/a-to-z/s/Seligman_10.pdf

Seligman, M. E. P. (2011a). Flourish: A visionary new understanding of happiness and well-being. New York: Free Press.

Seligman, M. E. P. (2011b). Authentic happiness: Flourish: A new theory of positive psychology (Archived newsletter). Retrieved from https://www.authentichappiness.sas.upenn.edu/ newsletters/flourishnewsletters/newtheory

Seligman, M. E. P. (2013). Authentic happiness: Using the new positive psychology to realize your potential for lasting fulfillment. New York: Atria Books.

Seligman, M. E. P., \& Csikszentmihalyi, M. (2000). Positive psychology. An introduction. American Psychologist, 55(1), 5-14.

Seligman, M. E. P., Rashid, T., \& Parks, A. C. (2006). Positive psychotherapy. American Psychologist, 61(8), 774-788. doi:10.1037/0003-066X.61.8.774

Seligman, M. E., Steen, T. A., Park, N., \& Peterson, C. (2005). Positive psychology progress: Empirical validation of interventions. American Psychologist, 60(5), 410-421. doi:10.1037/ 0003-066X.60.5.410

Shoshani, A., \& Steinmetz, S. (2014). Positive psychology at school: A school-based intervention to promote adolescents' mental health and well-being. Journal of Happiness Studies, 15(6), 1289-1311. doi:10.1007/s10902-013-9476-1

Smedley, J., Dick, F., \& Sadhra, S. (2013). Clinical tasks and procedures. In J. Smedley, F. Dick, \& S. Sadhra (Eds.), Oxford handbook of occupational health (pp. 747-770). Oxford, UK: Oxford University Press.

Smith, J. L., \& Hollinger-Smith, L. (2015). Savoring, resilience, and psychological well-being in older adults. Aging \& Mental Health, 19(3), 192-200. doi:10.1080/13607863.2014.986647

Southwick, S. M., Bonanno, G. A., Masten, A. S., Panter-Brick, C., \& Yehuda, R. (2014). Resilience definitions, theory, and challenges: Interdisciplinary perspectives. European Journal of Psychotraumatology, 5. doi:10.3402/ejpt.v5.25338 
Stanley, E. A., Schaldach, J. M., Kiyonaga, A., \& Jha, A. P. (2011). Mindfulness-based mind fitness training: A case study of a high-stress predeployment military cohort. Cognitive and Behavioral Practice, 18(4), 566-576. doi:10.1016/j.cbpra.2010.08.002

Tedlie Moskowitz, J., Carrico, A. W., Cohn, M. A., Duncan, L. G., Bussolari, C., Layous, K., et al. (2014). Randomized controlled trial of a positive affect intervention to reduce stress in people newly diagnosed with HIV; protocol and design for the IRISS study. Open Access Journal of Clinical Trials, 6, 85-100. doi:10.2147/OAJCT.S64645

Thompson, R. B., Peura, C., \& Gayton, W. F. (2014). Gender differences in the person-activity fit for positive psychology interventions. The Journal of Positive Psychology, 10(2), 179-183. doi:10.1080/17439760.2014.927908

Tugade, M. M., Fredrickson, B. L., \& Barrett, L. F. (2004). Psychological resilience and positive emotional granularity: Examining the benefits of positive emotions on coping and health. Journal of Personality, 72(6), 1161-1190. doi:10.1111/j.1467-6494.2004.00294.x

United States Coast Guard. (2014). Crew endurance management. Retrieved from http://www. uscg.mil/hq/cg $5 / \mathrm{cg} 5211 / \mathrm{cems}$.asp

U.S. Navy. (2015). Plan of the day announcements: Operational stress control. Retrieved from http://www.navy.mil/planOfDay.asp

van Wijk, C. H., \& Waters, A. H. (2008). Positive psychology made practical: A case study with naval specialists. Military Medicine, 173(5), 488-492.

Wang, H. (2008). Safety factors and leading indicators in shipping organizations: Tanker and container operations (A thesis submitted to the Graduate Faculty of Rensselaer Polytechnic Institute in partial fulfillment of the requirements for the degree of Doctor of Philosophy). Rensselaer Polytechnic Institute, Troy, New York. Retrieved from http://search.proquest.com/ docview/304531513

Waters, L. (2011). A review of school-based positive psychology interventions. The Australian Educational and Developmental Psychologist, 28(2), 75-90. doi:10.1375/aedp.28.2.75

WHO Europe. (2005). Mental health: Facing the challenges, building solutions; Report from the WHO European Ministerial Conference. Copenhagen, Denmark.: World Health Organization, Regional Office for Europe. Retrieved from http://www.euro.who.int/en/health-topics/ noncommunicable-diseases/mental-health/publications/2005/mental-health-facing-thechallenges,-building-solutions

Wood, J. V., Perunovic, W. Q. E., \& Lee, J. W. (2009). Positive self-statements: Power for some, peril for others. Psychological Science, 20(7), 860-866. doi:10.1111/j.1467-9280.2009.02370.x

Youssef, C. M., \& Luthans, F. (2007). Positive organizational behavior in the workplace: The impact of hope, optimism, and resilience. Journal of Management, 33(5), 774-800. doi:10. $1177 / 0149206307305562$

Zeidan, F., Johnson, S. K., Diamond, B. J., David, Z., \& Goolkasian, P. (2010). Mindfulness meditation improves cognition: Evidence of brief mental training. Consciousness and Cognition, 19(2), 597-605. doi:10.1016/j.concog.2010.03.014 
黛 Springer

http://www.springer.com/978-3-319-45428-3

Maritime Psychology

Research in Organizational \& Health Behavior at Sea

MacLachlan, M. (Ed.)

2017, XV, 241 p. 11 illus., Hardcover

ISBN: $978-3-319-45428-3$ 